\title{
COMPARISON OF WHITE AND BROWN LAYING HEN FARMS IN TERMS OF PERFORMANCE AND PROFITABILITY
}

\author{
Vecdi Demircan ${ }^{1}$, Hasan Yılmaz ${ }^{1}$, Hayati Koknaroglu ${ }^{2}$, Zeynep Dernek ${ }^{1}$, Mevlut Gul ${ }^{1}$, Tufan Bal ${ }^{1}$ \\ ${ }^{I}$ Department of Agricultural Economics, Faculty of Agriculture, Süleyman Demirel University, \\ Isparta, Turkey \\ ${ }^{2}$ Department of Animal Science, Faculty of Agriculture, Süleyman Demirel University, Isparta, Turkey \\ vecdem@ziraat.sdu.edu.tr
}

\begin{abstract}
In this study, white and brown laying hen farms in the Afyon province, which have considerable importance in laying hen farming in Turkey, were compared in terms of performance, and profitability and the most profitable genotype was determined. Data were obtained by conducting a questionnaire with 67 farmers. Laying hen farms were divided into two groups according to their genotypes and were analyzed accordingly. It was found that white layers had higher egg yield and better feed efficiency. Egg yield and feed efficiency for white and brown laying hen farms were $79.60,76.18 \%$ and $2.41,2.48 \mathrm{~kg}$ feed $/ \mathrm{kg}$ egg, respectively. It was also found that brown laying hen farms were advantageous in terms of economic criteria. Production cost and net profit per hen for white and brown laying hen farms were 28.62, 29.09 TL and 0.80, 3.78 TL, respectively ( $1 \mathrm{USD}=1.43 \mathrm{TL})$. The profit margin per egg for white and brown laying hen farms were $0.001,0.010 \mathrm{TL} / \mathrm{egg}$, respectively. The results showed that even though white laying hen farms had lower production costs, brown laying hen farms were more profitable and the reason for this was the higher price received per brown shell egg.
\end{abstract}

Key words: genotype; laying hen farms; performance; cost; profitability

\section{СПОРЕДБА НА БЕЛИ И КАФЕАВИ НЕСИЛКИ ВО ПОГЛЕД НА ПЕРФОРМАНСИТЕ И ПРОФИТАБИЛНОСТА}

\begin{abstract}
Бели и кафеави несилки одгледани во покраината Афион, коишто имаат големо значење во фармското одгледување на несилки во Турција, се споредувани во поглед на перформансите и профитабилноста и е одредуван најпрофитабилниот генотип. Податоците се добиени врз основа на анкетен прашалник од 67 фармери. Одгледуваните несилки беа поделени во две групи во зависност од нивниот генотип и беа соодветно анализирани. Се покажа дека белите кокошки имаат повисок удел на јајца и подобра конверзија на храна. Уделот на јајца и конверзијата на храна кај белите и кафеавите несилки беа 79,60, 76,18\% и 2,41, 2,48 kg храна $/ \mathrm{kg}$ јајца, соодветно. Исто така се покажа дека одгледувањето на кафеавите несилки е поповолно во однос на економските критериуми. Трошоците на производство и нето-добивката кај несилките од бела и кафеава линија беа 28,62, 29,09 турски лири (TL) и 0,80, 3,78 TL, соодветно (1 USD = 1,43 TL). Профитната граница по јајце за белите и кафеавите несилки беше $0,001,0,010 \mathrm{TL} /$ јајце, соодветно. Резултатите покажаа дека иако белите несилки имаа пониски трошоци при одгледувањето, кафеавите несилки сепак беа попрофитабилни, а причината за тоа била повисоката цена добиена по кафеаво јајце во лушпа.
\end{abstract}

Клучни зборови: генотип; несилки; перформанси; трошоци; профитабилност

\section{INTRODUCTION}

Livestock sector which plays a major role in sufficient and well-balanced nutrition of people has also economic and social functions so as to increase the national production and employment, to provide raw material for meat, milk, textile, leather, cosmetic and drug industry, to make a contribution to balanced development, to decrease and prevent the hidden and open unemployment in the rural area, to increase exchange income by export and to reduce immigration and its social troubles 
[Babacan, 2006]. Animal origin products are more nutritious for human nutrition. According to scientific studies, for each $\mathrm{kg}$ of body weight 1 gram of protein needs to be consumed in a day and $42 \%$ of this amount (30-35 g) should be animal-origin for healthy nutrition. Average protein consumption per capita in the developed countries is approximately $80-110$ gram and $50-60 \%$ of this comes from animal origin proteins [Şekerden ve Özkütük, 1993; Akman ve Kumlu, 1998; Aslan et al., 2002]. However, $73 \%$ of daily protein consumption in Turkey comes from plant-origin foods [Aslan et al., 2002].

Eggs are one of the animal-origin foods that have a great importance in an adequate and balanced diet for human beings. Two eggs consumed in one day can meet nearly half of animal-origin protein needs of a human being. When compared to the world average and developed countries, it was found that egg consumption per capita in Turkey was low. According to the data of 2005, annual egg consumption per capita was 115 in Turkey, the world average, USA, Japan, France, Germany and Austria were 144, 255, 330, 253, 206 and 228, respectively [Anonymous, 2008].

The poultry sector is known as the most developed animal branch in Turkey. Traditional village poultry production, which was expensive and with a limited production capacity was replaced by commercial and industrial poultry farms by increasing integrated hens farms and implementing the contract farming model from 1970 to 1980 . The poultry sector has reached global standards by large-size and modern investments by the private sector in 1990s [BESD-BİR, 2003]. In the poultry sector there are nearly 10000 broiler and 5000 egg production farms. It is estimated that around 2 million people earn their living from the poultry sector [DPT, 2007]. Due to the need for animal protein, the possibility of intensification, the contribution of scientific improvements to the field of breeding and feeding, the need for relatively smaller areas when compared to other animal husbandry branches and its contribution to the rural development, the poultry sector has an important role in the animal production.

The total number of broilers and laying hens in Turkey was 64078000 in 1990, in 2008 it reached 244280376 by a 4 -fold increase. The total egg production in Turkey increased around 2fold from 384930 tons to 824418 tons during the 1990-2008 period. The total number of laying hens in Turkey was 63364818 according to 2008 data, and the share of laying hens in the total number of poultry was around 26\% [TÜIK, 2008]. Turkey is ranked $14^{\text {th }}$ in the world in terms of egg production according to 2007 data [FAO, 2007]. Turkey's egg exports have increased 33 -fold between 2000-2008 reaching 120 million dollars from 3.6 million dollars. Main egg exported countries are Iraq, Syria, Azerbaijan and Saudi Arabia [DTM, 2008].

This study was carried out in the Afyon province of Turkey, which has a high potential for laying hen farming. The share of the Afyon province in Turkey in terms of egg production and export are $12 \%$ and $20 \%$, respectively [Anonymous, 2008]. In this study, white and brown laying hen farms were compared in terms of performance, production costs and profitability. Since the analysis of poultry farms having different genotypes in terms of economics aspects were not studied before in Turkey, this situation increases the importance of study.

\section{MATERIAL AND METHOD}

The data used in the study were obtained from the questionnaires administered to the producers at laying hen farms in the Afyon province. In addition, similar studies carried out by various persons and institutions and related statistics were also used. The data were collected in the year 2006.

Based on the data obtained from technical personnel in the Afyon Provincial Agricultural Administration and from the records of the laying hen farming sector, the Afyon province city center, Basmakc1, Bolvadin and Suhut counties, where laying hen farming is carried out, were selected as study areas. According to the records, there were 126 farms in the area. It was planned to interview all the farm owners; however, since some of the farms were closed down and some of the producers did not want to give information, only 75 producers were interviewed. It was determined that 53 of farms interviewed had white laying hens, 14 of farms had brown and 8 of farms have both genotypes, respectively. Since the purpose of this study was to compare laying hen farms according to white and brown genotypes, analyses were carried out on 67 farms. Then these farms were categorized into two groups according to genotypes, 
which were white (53 farms) and brown genotypes (14 farms). The data obtained from the farms were organized with the Excel software and are shown in tables. The GLM option in the SAS program [SAS, 1999] was used to determine significance levels of the dependent variables.

Depreciation costs were calculated for building and tool-machine capital. Depreciation ratio of $2,4,1.5$ and $5 \%$ were taken for concrete buildings, mud brick and wood buildings, stone buildings and machinery-equipment capital, respectively [Erkuş et al., 1995]. In the interest calculation of machinery-equipment and building capital, the formula below was used [Kiral et al., 1999].

Interest $=\frac{\text { Value of machine or building }}{2} \cdot$ Interest rate $(1)$

As year-end values of machinery-equipment and building capital were considered, the real interest rate was used. [Kadlec, 1985]:

$$
i=\frac{(1+r)}{(1+f)}-1
$$

where:

$i$ - real interest rate

$r$-nominal interest rate

$f$-inflation rate (WPI - Wholesale Price Index).

On the date when the questionnaire was administered, the annual nominal interest rate was $23.5 \%$ and the inflation rate was $11.58 \%$. So, the real interest rate was calculated as $10.68 \%$.

On the analyzed farms, generally more than one production activity was carried out. For this reason, fixed and variable costs for some machinery-equipment are common costs. In the distribution of common costs, utilization ratios of toolsmachines in laying hen farming were taken into account. General management costs were calculated by taking $3 \%$ of variable costs. In the calculation of wages for family members, the wages paid to non-family members in the region were used. In the cost calculation of egg production, since the eggs are produced and sold on a daily basis, revolving fund interest was not calculated [Kiral et al., 1999].

By addition of the values of the products obtained from laying hen farming, gross production value was found. By deducting variable costs from the gross production value, the gross profit was obtained. And by deducting production costs from the gross production value, the net profit was calculated and with the ratio of the gross production value to production costs, the relative return was calculated [Erkus et al., 1995; Rehber, 2005].

\section{RESULTS AND DISCUSSION}

The performance values of egg production on analyzed farms are given in Table 1 . It was found that the number of hen per farm was higher in the white laying hen farms. The number of hen per farm was found as 20740 in the white laying hen farms, it was found as 16228 in the brown laying hen farms. It was found that white hybrids in the study area were Lohmann, Nick Chick, Bovans White and the brown genotype were Hy-Line, Brown Nick, respectively. When the keeping period of hens in the egg production was analyzed, it was found that the brown laying hen farming had a longer period. The keeping period of white and brown genotype hens in the egg production was found to be 58.45 and 60.29 weeks, respectively. It was found that white hens tended to have higher egg yield per hen.

\section{Table 1}

Performance characteristics of hens in farms

\begin{tabular}{lcc}
\hline \multirow{2}{*}{} & \multicolumn{2}{c}{ Farm groups } \\
\cline { 2 - 3 } & White & Brown \\
\hline Number of hen (hen/farm) & 20740 & 16228 \\
Laying period (weeks) & 58.45 & 60.29 \\
Number of eggs per farm per day & 16509 & 12362 \\
Number of eggs per farm during & & \\
the laying period & 6754791 & 5216945 \\
Number of eggs per hen (egg/hen) & 325.69 & 321.48 \\
Egg yield (\%) & 79.60 & 76.18 \\
Mortality rate (\%) & 9.89 & 6.11 \\
\hline \hline
\end{tabular}

The egg production per white and brown hen was 325.69 and 321.48 eggs, respectively. In other studies Boğa et al. [2003], Mizrak et al. [2007a] and Mizrak et al. [2007b], found that the white laying hens had higher egg yield per hen than the brown laying hens. When the farms were analyzed 
in terms of egg yield, it was found that the white laying hen farms had higher yield. The egg yield (\%) was found to be $79.60 \%$ in the white laying hen farms, and $76.18 \%$ in the brown laying hen farms. According to this, the white laying hen farms were more advantageous than the brown laying hen farms. When the mortality rates on the farms were analyzed, the mortality rate was found lower in the brown laying hen farms compared to the white laying hen farms. It was observed that the mortality rate were $9.89 \%$ in the white laying hen farms and $6.11 \%$ in the brown laying hen farms. In the study of Tourchyan [2005], the mortality ratio was found to be higher in the white laying hen farms compared to the brown laying hen farms. Again, in the catalog of the Poultry Research Institution, the mortality rate was found to be higher in the white layers compared to the brown layers [TAE, 2009].

Feed consumption values of egg production on the farms are given in Table 2. According to the table, daily feed consumption per hen was 119.79 $\mathrm{g}$ in the white laying hen farms, and $118.71 \mathrm{~g}$ in the brown laying hen farms. Feed efficiency on the farms was determined in physical ( $\mathrm{kg}$ feed/ $\mathrm{kg}$ egg) and economic (TL feed/TL egg) terms. It was found that the white laying hens converted the feed better than the brown laying hens in physical terms but the brown laying hens in economic terms. Feed efficiency in physical terms was 2.41 and 2.48 , and the feed efficiency in economic terms was 0.73 and 0.67 , for white and brown laying hens, respectively. In the study of Ershad [2005] and Akünal (2009), it was found that the white layers were superior to the brown layers in terms of the feed efficiency.

Table 2

Feed consumption of hens in farms

\begin{tabular}{lcc}
\hline \hline & \multicolumn{2}{c}{ Farm groups } \\
\cline { 2 - 3 } & White & Brown \\
\hline Daily feed consumption (g/hen) & 119.79 & 118.71 \\
$\begin{array}{l}\text { Feed consumption during the laying period, } \\
\text { (kg/hen) }\end{array}$ & 49.00 & 49.91 \\
Feed efficiency (kg feed/kg egg) & 2.41 & 2.48 \\
Feed efficiency (TL feed/TL egg) & 0.73 & 0.67 \\
\hline \hline
\end{tabular}

$1 \mathrm{USD}=1.43 \mathrm{TL}$
Cost items of laying hen production were analyzed by categorizing them into fixed and variable costs. Egg production costs of farms are given in Table 3. As it is shown in the table, variable costs constituted a significant part of egg production period costs. The share of variable costs in the total costs was $74.87 \%$ in white layers, $74.43 \%$ in brown layers. The share of fixed costs in the total costs was 25.13, 25.57\% for white and brown genotypes, respectively. The main reason why variable costs share is high is the feed cost. Poultry feed prices nearly tripled in Turkey between 2000 and 2006 [DPT, 2007; Anonymous, 2008].

Table 3

Production costs of egg farms (TL)

\begin{tabular}{lcccc}
\hline \hline & \multicolumn{4}{c}{ Farm groups } \\
\cline { 2 - 5 } Cost items & White & $\%$ & Brown & $\%$ \\
\hline Feed & 407698.33 & 68.67 & 319939.72 & 67.77 \\
Electricity & 7271.32 & 1.22 & 2902.14 & 0.61 \\
Veterinary medication & 1933.96 & 0.33 & 2128.57 & 0.45 \\
Cleaning-disinfecting & 462.26 & 0.08 & 897.29 & 0.19 \\
Marketing & 570.28 & 0.10 & 589.29 & 0.12 \\
Packing & 21690.43 & 3.65 & 17166.00 & 3.64 \\
Machinery variable cost & 4126.90 & 0.70 & 7201.93 & 1.53 \\
Other costs & 752.30 & 0.13 & 529.43 & 0.11 \\
\hline A. Total variable costs & 444505.80 & 74.87 & 351354.36 & 74.43 \\
\hline Building capital interest & 5182.87 & 0.87 & 6293.57 & 1.33 \\
Building depreciation & 1941.15 & 0.33 & 2357.14 & 0.50 \\
Building repair cost & 1217.92 & 0.21 & 842.86 & 0.18 \\
Metal costs (A+B) & 593667.49 & 100.00 & 472089.14100 .00 \\
Rental cost of the hen house & 366.04 & 0.06 & 368.57 & 0.08 \\
Machinery capital interest & 5573.45 & 0.94 & 5238.09 & 1.11 \\
Machinery depreciation & 5218.59 & 0.88 & 4904.58 & 1.04 \\
\hline & 14568.08 & 2.45 & 22622.27 & 4.79 \\
Prowing cost of chick & 101758.41 & 17.14 & 67567.07 & 14.31 \\
\hline & 13335.17 & 2.25 & 10540.63 & 2.23 \\
\hline
\end{tabular}


On the analyzed farms, the feed cost ranks first among the cost items making up the total cost. The share of the feed cost in the total costs in the white and the brown layers was 68.67 and $67.77 \%$, respectively. These results are parallel to the results obtained in other studies. Bayaner [1999] reported that the share of the feed cost in the total costs was $67.82 \%$. Bostan [1980] found that the share of the feed costs in the total production costs was $73.4 \%$ on average.

To minimize feed costs, which constitute the most important expense in laying hen farming, necessary precautions should be taken. Since corn and soy, the raw materials of poultry feed in Turkey, are not produced in adequate amounts, 30\% of the corn and $90 \%$ of the soy are imported [TKB, 2004]. To enable adequate production of corn and soy in Turkey and to reduce dependency on external sources, incentive premiums should be increased. Another important cost item in the egg production period is chick growing costs. The farms in the investigated area obtain chicks from several grower companies and they feed them until the egg production period. The share of the chick growing cost in the production costs was $17.14 \%$ in the white layers and $14.31 \%$ in the brown layers.

Gross production values of the gross egg production on the analyzed farms are given according to the genotypes in Table 4. As it is indicated in the table, the gross production value in the egg production includes egg sales, reformed chicken sales, the slaughtered hen value and the fertilizer production value. According to the survey results, the gross production value was found higher in the white laying hen farms. The gross production value per farm was found as $610177.76 \mathrm{TL}$ and 533425.55 TL, for the white and the brown genotypes, respectively. Egg sales constituted a significant part of the gross production value. The share of egg sales in the total gross production values was $97.13 \%$ in the white layers, $95.66 \%$ in the brown layers.

The gross, net and relative return per farm and per hen in the study area according to the genotypes is given in Table 5. The gross profit is an important success criterion in determination of the competitiveness of production, in terms of utilization of inadequate production factors on the farm. In other words, the gross profit is an important criterion that indicates the success of the farm organization [Erkuş et al., 1995]. It is found that on the analyzed farms, the average gross profit per farm was higher in the brown laying hen farms and these farms were more successful than the white laying hen farms in terms of management principles. In fact, the average gross profit was 165671.97 TL in the white laying hen farms and 182071.19 TL in the brown laying hen farms. Brown laying hen farming was found more advantageous in terms of average net profit per farm. In fact, the average net profit per farm in the white laying hen farms and the brown laying hen farms was calculated as $16510.27 \mathrm{TL}$ and $61336.42 \mathrm{TL}$, respectively.

\section{Table 4}

Income of laying hen farms

\begin{tabular}{|c|c|c|c|c|}
\hline \multirow{3}{*}{ Income items } & \multicolumn{4}{|c|}{ Farm groups } \\
\hline & \multicolumn{2}{|c|}{ White } & \multicolumn{2}{|c|}{ Brown } \\
\hline & TL & $\%$ & $\mathrm{TL}$ & $\%$ \\
\hline Egg sales & 592651.03 & 97.13 & 510264.48 & 95.66 \\
\hline Discarded hens sales & 2785.11 & 0.46 & 6357.36 & 1.19 \\
\hline Destroyed hen value & 12352.17 & 2.02 & 16225.00 & 3.04 \\
\hline Fertilizer sales & 2389.45 & 0.39 & 578.71 & 0.11 \\
\hline
\end{tabular}

Total gross values product 610177.76100 .00533425 .55100 .00

Table 5

Gross profit, net profit and relative return in farms

\begin{tabular}{lcc}
\hline \hline & \multicolumn{2}{c}{ Farm groups } \\
\cline { 2 - 3 } Values (TL/ Farms) & White & Brown \\
\hline Gross product value & 610177.76 & 533425.55 \\
Variable costs & 444505.80 & 351354.36 \\
Production costs & 593667.49 & 472089.14 \\
Gross profit & 165671.97 & 182071.19 \\
Net profit & 16510.27 & 61336.42 \\
Relative return & 1.03 & 1.13 \\
\hline Values (TL/hen) & & \\
\hline Gross product value & 29.42 & 32.87 \\
Variable costs & 21.43 & 21.65 \\
Production costs & 28.62 & 29.09 \\
Gross profit & 7.99 & 11.22 \\
Net profit & 0.80 & 3.78 \\
Relative return & 1.03 & 1.13 \\
\hline \hline
\end{tabular}


Another criterion of evaluating the success of laying hen farming is the relative return. The relative return indicates the income corresponding to one TL cost. To consider a farm successful, the relative return should be higher than the one. On the analyzed farms, the relative return in the white and the brown laying hen farms was 1.03 and 1.13, respectively. Since the relative return was higher than one in both genotypes, these farms made a profit. But profitability of brown laying hens was higher.

In the study area, in addition to the amount of gross, net and relative return per farm, the amounts per hen for white and brown hen farming were also calculated. The gross profit per hen on the analyzed farms was 7.99 and $11.22 \mathrm{TL}$, respectively for the white and brown hen genotypes. The net profit per hen was $0.80 \mathrm{TL}$ in the white laying hen farms, $3.78 \mathrm{TL}$ in the brown laying hen farms. According to these results it could be implied that the brown laying hen farms were more profitable compared to the white laying hen farms (Table 5).

The egg cost and profit margins of the analyzed farms are given in Table 6.

Table 6

Cost and profit margin of eggs in farms

\begin{tabular}{|c|c|c|}
\hline & \multicolumn{2}{|c|}{ Farm groups } \\
\hline & White & Brown \\
\hline A. Production costs (TL/ farm) & 593667.49 & 472089.14 \\
\hline B. Discarded hen sales (TL/ farm) & 2785.11 & 6357.36 \\
\hline C. Destroyed hen value (TL/ farm) & 12352.17 & 16225.00 \\
\hline D. Fertilizer sales (TL/ farm) & 2389.45 & 578.71 \\
\hline $\begin{array}{l}\text { E. Number of eggs per farm during } t \\
\text { laying period }\end{array}$ & 6754791 & 5216945 \\
\hline F. Egg cost (TL/egg) (A-B-C-D/E) & 0.085 & 0.086 \\
\hline G. Egg cost (TL/kg) & 1.365 & 1.377 \\
\hline H. Egg sales price (TL/egg) & 0.086 & 0.096 \\
\hline I. Profit margin (TL/egg) (H-F) & 0.001 & 0.010 \\
\hline
\end{tabular}

Reformed chicken sales and fertilizer sales were deducted from the average production costs per farm and the remaining value was assigned to the total egg production and the unit egg cost was calculated. Then by taking the difference between the sales price and the cost of an egg, the profit margin was calculated. It was found that cost of one kg-egg in the white laying hen farms was less than the brown laying hen farms. In fact, the cost of one kg-egg in the white and the brown hen farms was 1.365 and $1.377 \mathrm{TL}$, respectively. In addition to the cost of one kg-egg, the cost of one egg was calculated. The cost of one egg in the white and the brown hen farms was 0.085 and $0.086 \mathrm{TL}$, respectively. However, it was found that the profit margin was higher in the brown hen farms. The profit margin in the white and the brown hen farms was 0.001 and $0.010 \mathrm{TL} / \mathrm{egg}$, respectively.

\section{CONCLUSION}

In this study, the white and the brown laying hen farms in the Afyon province, which have considerable importance in laying hen farming in Turkey, were compared in terms of performance, production cost, feed consumption and profitability and the most profitable genotype type was determined. According to the results, white laying hen farms were more advantageous in terms of the egg yield and better feed efficiency. However, brown laying hen farms were more advantageous in terms of economic criteria. In fact, it was found that in the study area, the gross, net and relative return were higher in the brown laying hen farms compared to the white laying hen farms. The results showed that the profit margins were higher in the brown laying hen farms. For this reason, brown laying hen farms should be pursued to enhance their activities in this region. Training and extension activities should be organized for the egg producers. For reducing feed costs in laying hen farming, raw feed materials (corn, soy, sunflower) should be supported to a higher extent. The poultry sector is dependent on external sources in terms of breeding stock. A considerable amount of various products manufactured using advanced technologies (vaccinations, antibiotics, biological and chemical substances, feed additives, growth factors), and the poultry-house, the hatchery, feed factory and the slaughterhouse equipment are also imported from abroad. All of these factors significantly increase production costs and adversely affect the international competitiveness of the poultry sector. For this reason, Turkey should develop its own breeding stock for breeding. In addition, investments in manufacturing all the above men- 
tioned products in Turkey should be encouraged. The instability of prices, especially due to supplydemand imbalance in the egg production, may force producers to sell their products below their costs. Like developed countries, excess eggs on the market should be processed by industrial facilities, turning them into more durable products, such as pasteurized liquid egg and egg powder.

Acknowledgment: This Research was supported by the Unit of the Scientific Research Project of Suleyman Demirel University (Project No. 1375-M-06)

\section{REFERENCES}

[1] Akman, N., Kumlu, S. (1998): Türkiye Hayvancılığının Örgütlenme Sorunlar1. II. Zootekni Kongresi, 22-25 Eylül, Bursa, 34-52.

[2] Akünal, T. (2009): Farklı Ticari Yumurtacı Hibritlerin Sürdürülebilirlik Açısından İncelenmesi. Yüksek Lisans Tezi, Süleyman Demirel Üniversitesi, Fen Bilimleri Enstitüsü. Zootekni Ana Bilim Dalı, Isparta.

[3] Anonymous (2008): Türkiye Yumurta Üreticileri Birlği. http://www.yumbir.org.tr/.

[4] Aslan, S., Bozdoğan, Ş., Uzun, T., Gökmen, C. (2002). Tarım Sektöründe Hayvancılık ve 50. Yilında Et ve Balık Kurumu. Et ve Balık Ürünleri A. Ş. Genel Müdürlügü. Yayınlanmamış Rapor. Ankara.

[5] Babacan, S. (2006): AB Sürecinde Türkiye Hayvancllı sektörünün Avantaj ve Dezavantajlart. İzmir Ticaret Odası Yayınları, İzmir.

[6] Bayaner, A. (1999): Çorum İlinde Yumurta Tavukçuluğunun Ekonomik Analizi. Tarımsal Ekonomi Araștırma Enstitüsü Yayınları No. 23, Ankara.

[7] BESD-BİR (2003): BESD-BİR (Beyaz Et Sanayicileri ve Damızlıkçılar Birliği). Kanatlı Bilgileri Yıllığı, Yayın No. 4. Ankara.

[8] Boğa A. G., Koçanaoğullari S., Uysal A., Akdeniz S. (2003): Beyaz ve Kahverengi yumurtac1 saf hatlardan elde edilen ebeveynler ile bunların ikili, üçlü ve dörtlü melezlerinin çeşitli verimler bakımından karşılaştırılması. Tarım ve Köyişleri bakanlığı TAGEM-HAYSÜD Kanatlı Yetiştiriciliği Program Değerlendirme ve Planlama Toplantısı Sonuç Raporu (Basılmamış). Ankara.

[9] Bostan, M. (1980): İstanbul İli Tavukçuluk İşletmelerinin Ekonomik Yapısı ve Temel Yöntem Sorunları. İ. Ü. Veterinerlik Fakültesi Biyoistatistik ve Hayvancılık İşletme
Ekonomisi Kürsüsü (Yayınlanmamıs Doktora Tezi), İstanbul.

[10] DPT (2007): DPT (T.C. Başbakanlık Devlet Planlama Teşkilatı), VIII Beş Yıllık Kalkınma Planı, Hayvancılık Özel İhtisas komisyonu Raporu, Ankara.

[11] DTM (2008): DTM (Dış Ticaret Müsteşarlığı Ege İhracatç1lar Birliği). http://www.egebirlik.org.tr/.

[12] Erkuş, A., Bülbül, M., Kiral, T., Açil A. F., Demirci R., (1995): Tartm Ekonomisi. Ankara Üniversitesi Ziraat Fakültesi Eğitim, Araştırma ve Geliştirme Vakfı Yayinları, Ankara.

[13] Ershad, S.M.E. (2005): Performance of hybrid layers and native hens under farmers management in a selected area of Bangladesh. International Journal of Poultry Sciences 4 (4), 228-232.

[14] FAO (2007): FAO (Food and Agriculture Organization). http://www.fao.org/.

[15] Kadlec, C. E. (1985): Farm Management, Decisions, Operation, Control, Prentice-Hall,Inc.

[16] Kiral, T., Kasnakoğlu, H., Tatlidil, F., Fidan, H., Gündoğmuş, E. (1999): Tarımsal Ürünler İçin Maliyet Hesaplama Metodolojisi ve Veri Tabanı Rehberi. Tarımsal Araştırma Enstitüsü, Yayın No. 37, Ankara.

[17] Mizrak, C., Boğa, A. G., Erkuş, T. (2007a): Ankara Tavukçuluk Araştırma Enstitüsünde geliştirilen kahverengi yumurtacı ebeveyn ve hibritlerin çeşitli verim özellikleri. Tavukçuluk Araştırma Enstitüsü Dergisi, 7 (1), 10-17.

[18] Mizrak, C., Boğa, A. G., Erkuş, T. (2007b): Ankara Tavukçuluk Araştırma Enstitüsünde geliştirilen beyaz yumurtacı ebeveyn ve hibritlerin çeşitli verim özellikleri. Tavukçuluk Araştırma Enstitüsü Dergisi, 7 (1), 17-22.

[19] Rehber, E. (2005): Tarımsal İşletmecilik ve Planlama. Uludağ Üniversitesi Güçlendirme Vakfi Yayın, No. 84, Bursa.

[20] SAS (1999): Statistical Analysis Systems User's Guide. $8^{\text {th }}$ ed. SAS Institute Inc., Raleigh, North Carolina, USA.

[21] Şekerden, Ö., Özkütük, K. (1993): Büyükbaş Hayvan Yetiştirme. Çukurova Üniversitesi Ziraat Fakültesi Ders Kitabl, No. 122. Adana.

[22] TAE (2009): TAE (Tavukçuluk Araştırma Enstitüsü), Hibrit Katalogları, http://www.tae.gov.tr/index.php

[23] TKB (2004): TKB (Tarım ve Köyişleri Bakanlı̆̆ı), II. Tarım Şurası Çalışma Belgesi, Ankara.

[24] Tourchyan, K. (2005). Yerli ve Dış Kaynaklı Beyaz Yumurtacı Hibritlerin Verim Özellikleri Bakımından Karşılaştırılması. Yüksek Lisans Tezi, Ankara Üniversitesi Fen Bilimleri Enstitüsü, Ankara.

[25] TÜIKK (2008): TÜIK (Türkiye Istatistik Kurumu) Tarımsal Yapı (Üretim, Fiyat, Değer). Ankara. 
